\title{
Determinants of Village Chicken Products Price and Productivity in Central Ethiopia
}

\author{
Minyahel Tilahun Mosa Mitiku \\ College of Agriculture and Natural Resources Department of Animal Production and Technology, Wolkite \\ University, Wolkite, Ethiopia \\ ORCID 0000-0002-1469-191X
}

\begin{abstract}
A total of 180 households (HHs) were selected from Gurage zone of Ethiopia, and 80 eggs were collected and assessed for quality. All collected descriptive data were analyzed using SPSS version 20, and mean differences were separated using Least Significant Difference (LSD). The result indicated that using young chick and hen keeping as parameter was showed a significant difference $(\mathrm{P}<0.05)$ between the two selected agro ecologies of the study area. All village chicken productivity estimating parameters i.e. eggs/hen $/$ week, eggs/hen/clutch, eggs /hen/year, hatchability and mortality were showed a significant difference at all $\mathrm{P}$ levels $(\mathrm{P}<0.05 ; \mathrm{P}<0.01 ; \mathrm{P}<0.05)$ with in and across the agro ecologies. Married respondents $(60 \%)$ and respondents who attain elementary education $(60 \%)$ were the major participant of different marketing activities. However of village chicken products marketing were highly determined by stage of marketand majorly $(65 \%)$ marketed at farm gate and at primary markets, secondary markets showed significance difference $(\mathrm{P}<0.05)$ on the price of selling chicken and egg. Christian holydays and Ethiopian New Year showed a significant difference among the selected study areas for selling of local and crossbred chicken and egg. Seasonal demands and festive periods were the two major determining factors which create price inflation. Price fluctuation, seasonal demand and intermediaries were the first three major constraints in the process of marketing chickens and eggs, respectively. All available market places in the study area did not have special infrastructure which helped chicken and eggs to be sold independently.
\end{abstract}

Keywords: Cheha, marketing, production, productivity, village chicken.

DOI: $10.7176 /$ JNSR/9-19-03

Publication date:October $31^{\text {st }} 2019$

\section{Introduction}

Poultry is the largest group of livestock species contributing about $33 \%$ of all animal protein consumed in the world (FAO, 2010). Chicken source food products contain high-quality protein and micronutrients which can supplement adequate nutrient to the common traditional diets drawn from staple crops (De Bruyn et al., 2015). Ethiopia has an estimated 65 million chicken population of which nearly $98 \%$ of the chicken population has been predominantly managed by traditional poultry production system (CSA, 2017).

Village chicken keeping in Ethiopia refers to the practice which involves the production of mostly small flocks of local, cross and exotic chickens largely using scavenging feed resources (Aklilu, 2007). It is characterized by low input and output, low provision of feed and health care and high mortality rates. Despite their low productivity, village chicken production is still used as food and income source and also offers socio-cultural advantages (Fisseha et al., 2010a). It has a number of opportunities to the poor HHs to improve their livelihood. It demands small investment as compared to other livestock production systems (Lawal et al., 2016). This characteristic can open room for the poor $\mathrm{HH}$ to participate in such business to support their livelihood. In addition, temperature tolerant, disease resistant, good egg and meat flavor, hard egg shells, high fertility and hatchability and high dressing percentage are significant characteristics which should be conserved and passed to the future (Mekonnen, 2007). The high genetic diversity of the majority chicken population (i.e., local chicken breeds) has been serving as genetic reservoirs for present and future genetic improvements of local chickens (Nigussie et al., 2010; Emebet et al., 2014).

Even if village chicken production does not require investments beyond the cost of the foundation stock (USAID, 2010), shortage of animal protein availability is still a major problem and become the common cause for infant mortality (Mengasha, 2011). Live village chickens and eggs have been marketed to the local and urban markets or directly to consumers. Increasing distance from markets minimizes selling chicken products for direct consumers and also forces to sell their product with a low price (Aklilu, 2007). The above stated problem and other related problems are exacerbated when coupled up with human population growth and urbanization (Abdullah et al., 2011).

Since 1970's, Ethiopia has been attempting to introduce different exotic chicken breeds and distribute to small holder farming to improve the low egg production performance of local chicken. Similar international parameters i.e., average number of eggs, laying period per hen per annum, the length of a single egg-laying period per hen and average number of eggs laid per hen per egg-laying period has been used to estimate chicken egg production capacity (Alem et al., 2014). The potential the country has in terms of village chicken production has been 
overlooked and proper interventions has not been yet implemented (Nigussie et al., 2010). Numbers of reasons have been reported for the low return of the chicken production system in Ethiopia. But, among these, the basic ones are overlooking the socio-economic and institutional context under which the HHs operate (Tadesse \& Tesfay, 2013), and exterminating indigenous knowledge and management practice in the process of developing chicken production strategies at country level (Fisseha et al., 2010). In addition, low effort has been invested to document activities which have been undertaken to improve chicken productivity at farm level. Therefore, solving the identified constraints and perceiving village chicken production characteristics and marketing trends, success and constraints would allow developing a proper and feasible strategy which can improve village chicken productivity and select the proper breed and production system. In return, it can be used as a mechanism to reduce poverty and malnutrition among rural and urban poor, as well as increasing national income (Shapiro et al 2015). Therefore, this study was initiated to attain the following objectives: to characterize and evaluate village chicken productivity; to assess village chicken and egg marketing practices and constraints.

\section{Material and methods}

\subsection{Description of the Study Area}

The study was conducted in Gurage zone; Southern Nations, Nationalities and Peoples' Regional State (SNNPRS), Ethiopia (Figure 1). The study area is found $188 \mathrm{~km}$ to the south direction from the capital city of Ethiopia, Addis Ababa. The geographical location of the study area extends from $8^{\circ} 00^{\prime} 18.9^{\prime \prime}$ to $8^{\circ} 15^{\prime} 28.53^{\prime \prime}$ North and $37^{\circ} 35^{\prime}$ $46.48^{\prime \prime}$ to $38^{\circ} 03^{\prime} 59.59^{\prime \prime}$ East at an elevation ranging from 1,900 to 3,000 meters above sea level (m.a.s.l). The area majorly hosts high (2401-3000 m.a.s.l) and mid (1900-2400 m.a.s.1) altitude agro-climatic zone. The average annual rainfall of the district has been about $1268.04 \mathrm{~mm}$, and the average maximum and minimum temperature in the study area is $24.97^{\circ} \mathrm{C}$ and $10.69^{\circ} \mathrm{C}$, respectively.

\subsection{Research Methodology}

A survey research design was employed for this study, and accomplished through formal face to face interview with the selected respondents. The developed semi- structured questionnaire was pre-tested and augmented with Focus Group Discussions (FGDs), Key Informant Interview (KIIs) and field observations to triangulate the collected data convenience with the data from formal survey.

\subsection{Sample size determination and sampling procedure}

Agricultural activities such as cropping and livestock production are common in Gurage zone of Ethiopia. The study areas mostly cover all agro ecologies and village chicken production is common in two of the major agroecological classification i.e., Mid land and Highlands. A total of six PAs(Kebeles) which represent the two agro ecologies i.e., namely Yeferezye, Girar and Yedebe was selected from from High land and Gassore, Awan and Sisenaematye kebeles was selected from Mid land based on their production potential and ease of accessibility. A total of $180 \mathrm{HHs}$ i.e., equal and manageable sample size of 30 per from each PAs were purposively selected based on their chicken producers experience. In the study area, only four local markets were found around the selected PAs, hence marketing related survey was undertaken using a sample size of 20 egg and chicken traders of the existing four local markets. A total of 80 chicken and egg traders were incorporated in the study. In addition, the study involved respondents who hold any chicken breed and chicken blood levels. A total of two FGDs from each agro ecologies composed of 24 participants (18 females and 6 males) were involved. The participants were selected based on their experience towards village chicken management practice and chicken production potential, chicken ownership pattern and decision making.

The study used multi stage purposive sampling based on the chicken production potential and road and market accessibility. The study district i.e., Cheha district was selected among the other districts of Gurage zone based on the defined chicken and egg production criteria developed for the study. Information related to the necessary information to the study was collected from the zonal agricultural office.

\subsection{Data collection methods}

Before commencement of the formal survey, a pretest was conducted on twelve randomly selected HHs on the selected study areas. Moreover, the information regarding chicken distribution, population and contribution of village chickens were obtained from Gurage zone Agriculture and Rural development office.

\subsection{Statistical Analysis}

All descriptive data were analyzed using SPSS(Statistical Package for Social Sciences) version 20software and mean differences were separated using Least Significant Difference (LSD). The mean statistics (Mean, SEM and percentage)for continuous variables obtained from the survey were subjected to analysis of variance (ANOVA) using the General Linear Model (GLM) procedure of SPSS based on the two agro-ecology and available chicken breeds. The model was described as follow: 
$\mathbf{Y i j k}=\boldsymbol{\mu}+\mathbf{A} \mathbf{i}+\mathbf{B j}+(\mathbf{A B}) \mathbf{i j}+\mathbf{C i}_{\mathbf{j} \mathbf{k}}$

Where: $\mathrm{Y}_{\mathrm{ijk}}=$ production and productivity performance as affected by agro ecology, breed and their interactions, $\mu=$ Overall mean of the respective variables, $A_{i}=$ the effect of $i^{\text {th }}$ agro-ecology ( $i=$ high and mid land)production and productivity performance, $\mathrm{B}_{\mathrm{j}}=$ the effect of $\mathrm{j}^{\text {th }}$ chicken breed ( $\mathrm{j}=$ local and crossbred chicken breed)on production and productivity performance, $(\mathrm{AB})_{\mathrm{ij}}=$ the interaction effect between agro-ecology and chicken breed on production and productivity performance ; and $\epsilon_{\mathrm{ijk}}=$ the $\mathrm{ijk}^{\text {th }}$ random error.

\section{Results}

\subsection{Chicken Breed Composition and Flock Size}

The overall mean value of chicken breed composition and flock size in the district is presented in Table 1. The dominant class of chicken owned by respondents was hens (40.3\%) followed by young chick (34\%). Yong chicken keeping showed a significant difference $(\mathrm{P}<0.05)$ between high and mid land. Households from mid land owned a slightly higher average chicken population (11.0) as compared to high land HHs (10.17).

\begin{tabular}{|c|c|c|c|c|c|}
\hline \multirow[b]{2}{*}{ Parameters } & \multicolumn{2}{|c|}{ Agro-Ecology } & \multirow{2}{*}{$\begin{array}{l}\text { Overall Mean } \\
\qquad(\mathrm{N}=180)\end{array}$} & \multirow[t]{2}{*}{$(\%)$} & \multirow[t]{2}{*}{ P-value } \\
\hline & $\mathrm{HL}(\mathrm{n}=90)$ & $\operatorname{ML}(n=90)$ & & & \\
\hline \multicolumn{6}{|l|}{ Local chicken } \\
\hline Hens & $4.32 \pm 0.12$ & $4.23 \pm 0.22$ & $4.27 \pm 0.12$ & 40.34 & $0.731^{\mathrm{NS}}$ \\
\hline Cocks & $0.85 \pm 0.06$ & $0.88 \pm 0.07$ & $0.87 \pm 0.46$ & 8.22 & $0.811^{\mathrm{NS}}$ \\
\hline Pullets & $0.90 \pm 0.08$ & $0.94 \pm 0.08$ & $0.92 \pm 0.05$ & 8.69 & $0.708^{\mathrm{NS}}$ \\
\hline Cockerels & $0.90 \pm 0.08$ & $0.93 \pm 0.08$ & $0.91 \pm 0.05$ & 8.60 & $0.778^{\mathrm{NS}}$ \\
\hline Young chicks & $3.20 \pm 0.14^{\mathrm{b}}$ & $4.02 \pm 0.12^{\mathrm{a}}$ & $3.61 \pm 0.10$ & 34.12 & $* *$ \\
\hline Total & 10.17 & 11.00 & 10.58 & 100 & - \\
\hline \multicolumn{6}{|c|}{ Crossbred (Sasso) chicken } \\
\hline Hens & $0.37 \pm 0.04^{\mathrm{b}}$ & $0.58 \pm 0.05^{\mathrm{a}}$ & $0.47 \pm 0.04$ & 27.45 & $*$ \\
\hline Cocks & $0.40 \pm 0.05$ & $0.40 \pm 0.04$ & $0.40 \pm 0.04$ & 23.31 & $0.77^{\mathrm{NS}}$ \\
\hline Pullets & $0.42 \pm 0.04$ & $0.34 \pm 0.05$ & $0.38 \pm 0.04$ & 19.68 & $0.29^{\mathrm{NS}}$ \\
\hline Cockerels & $0.36 \pm 0.05$ & $0.32 \pm 0.05$ & $0.34 \pm 0.03$ & 17.62 & $0.64^{\mathrm{NS}}$ \\
\hline Young chicks & $0.14 \pm 0.04^{\mathrm{b}}$ & $0.24 \pm 0.03^{\mathrm{a}}$ & $0.19 \pm 0.03$ & 12.47 & $* *$ \\
\hline Total & 1.69 & 1.88 & 1.78 & 100 & - \\
\hline Total & 11.86 & 12.88 & 12.36 & - & - \\
\hline \multicolumn{6}{|c|}{$\begin{array}{l}a-b=\text { Least square means with different superscripts within a row are significantly different }(P<0.05) ; \\
\text { SEM=Standard Error of Mean; NS=Not Significant; } *=\text { Significant at } P=0.05 ; * *=\text { Significant at } P<0.001 ; \\
H L=\text { indicate High land; } M L=\text { Mid land }\end{array}$} \\
\hline
\end{tabular}

\subsection{Purpose of Keeping Chicken and Egg Production}

Table 2 presents purposes of keeping chicken in village chicken producers. Sale for income, egg production, home consumption/entertaining guests, hatching/breeding, cultural/religious and employment were the major reasons reported for keeping chicken in the district, respectively. Majority (48\%) of respondents was keeping chicken for generating immediate income and it is followed by use of egg for brooding/hatching purpose.

\begin{tabular}{|c|c|c|c|c|c|c|c|}
\hline \multirow[b]{3}{*}{ Variables } & \multirow[b]{3}{*}{ Description } & \multicolumn{4}{|c|}{ Agro-Ecology } & \multirow{3}{*}{$\begin{array}{l}\text { Overall } \\
\mathrm{N}(\%)\end{array}$} & \multirow[b]{3}{*}{ rank } \\
\hline & & $\mathrm{HL}$ & & ML & & & \\
\hline & & $\mathrm{n}(\%)$ & rank & $\mathrm{n}(\%)$ & rank & & \\
\hline \multirow{6}{*}{$\begin{array}{l}\text { Purposes of keeping } \\
\text { chickens }\end{array}$} & Sale for income & $47(52.22)$ & 1 & $40(44.44)$ & 1 & $87(48.34)$ & 1 \\
\hline & Home consumption & $13(14.44)$ & 3 & $19(21.11)$ & 2 & $32(17.78)$ & 3 \\
\hline & Hatching (breeding) & $4(4.44)$ & 4 & $8(8.89)$ & 4 & $12(6.67)$ & 4 \\
\hline & Create job opportunity & $3(3.33)$ & 5 & $3(3.33)$ & 5 & $6(3.33)$ & 5 \\
\hline & Egg production & $20(22.22)$ & 2 & $17(18.89)$ & 3 & $37(20.55)$ & 2 \\
\hline & Cultural/religious & $3(3.33)$ & 5 & $3(3.33)$ & 5 & $6(3.33)$ & 5 \\
\hline \multirow{3}{*}{$\begin{array}{l}\text { Purpose of eggs } \\
\text { production }\end{array}$} & Hatching & $48(53.33)$ & 1 & $41(45.6) 7$ & 1 & $89(49.44)$ & 1 \\
\hline & Sale for income & $28(31.11)$ & 2 & $25(27.78)$ & 2 & $53(29.44)$ & 2 \\
\hline & Home consumption & $14(15.56)$ & 3 & $24(26.67)$ & 3 & $38(21.12)$ & 3 \\
\hline
\end{tabular}

$H A, M A, N$ and $n$ represents High land, Mid land and total Number of market participants, number of participants from the two altitudes, respectively. 


\subsection{Productivity of Village Chickens}

Productivity of village chickens in Cheha district was presented in Table 3 . The result of this study indicated that agro-ecologies (in and between) difference had a significance difference with the different parameters used to characterize chicken and egg production capacity. The average number of eggs produced from local chickens showed a better hatchability (80.3) as compared to egg produced from crossbreds (65.23). Even if the number of egg produced per hen/year between the two agro ecologies and the breeds did not have a higher value difference, the test shows a significance difference of at least $(\mathrm{P}<0.05)$. There was significant difference between the two agro-ecologies and chicken breeds at $(\mathrm{P}<0.05, \mathrm{P}<0.01$ and $\mathrm{P}<0.05)$ for hatchability.

Local chickens laid an average of $56.57 \mathrm{Eggs} / \mathrm{year}$ which is significantly lower than cross breed chicken (174.27 eggs/ year).There was also, a significant difference between the two agro-ecologies $(\mathrm{P}<0.01)$ on chicken mortality.

\begin{tabular}{|c|c|c|c|c|c|c|c|c|c|}
\hline \multicolumn{10}{|c|}{ Table 3.Productivityof village chicken $(\mathrm{N}=180 ; n=90)$} \\
\hline \multirow[b]{2}{*}{ Parameters } & \multicolumn{2}{|c|}{ A-E $($ Mean \pm SEM $)$} & \multirow{2}{*}{$\begin{array}{l}\text { Overall } \\
\text { Mean }\end{array}$} & \multirow[b]{2}{*}{ SL } & \multicolumn{2}{|c|}{ Breed(Mean \pm SEM) } & \multirow{2}{*}{$\begin{array}{l}\text { Overall } \\
\text { Mean }\end{array}$} & \multirow[b]{2}{*}{ SL } & \multirow{2}{*}{$\begin{array}{l}\text { AEX } \\
\text { CB }\end{array}$} \\
\hline & HL & ML & & & Local & Crossbred & & & \\
\hline Eggs/hen/week & $4.14 \pm 0.86^{\mathrm{b}}$ & $4.55 \pm 0.22^{\mathrm{a}}$ & $4.34 \pm 0.54$ & $*$ & $3.52 \pm 0.06^{\mathrm{b}}$ & $6.17 \pm 0.02^{\mathrm{a}}$ & $4.84 \pm 0.04$ & $*$ & $*$ \\
\hline Eggs/hen/clutch & $14.11 \pm 0.45^{b}$ & $14.58 \pm 0.02^{\mathrm{a}}$ & $14.35 \pm 0.24$ & $*$ & $12.57 \pm 0.16^{\mathrm{b}}$ & $18.11 \pm 0.10^{\mathrm{a}}$ & $15.34 \pm 0.13$ & ** & * \\
\hline Eggs /hen/year & $114.10 \pm 0.11^{\mathrm{b}}$ & $116.53 \pm 0.12^{\mathrm{a}}$ & $115.32 \pm 012$ & $*$ & $56.57 \pm 0.39^{\mathrm{b}}$ & $174.27 \pm 1.12^{\mathrm{a}}$ & $115.42 \pm 0.75$ & *** & $*$ \\
\hline Hatchability $\%$ & $70.13 \pm 0.22^{b}$ & $75.37 \pm 0.46^{\mathrm{a}}$ & $72.75 \pm 0.34$ & $*$ & $80.28 \pm 0.45^{\mathrm{a}}$ & $65.23 \pm 0.14^{\mathrm{b}}$ & $72.75 \pm 0.29$ & $* *$ & $*$ \\
\hline $\begin{array}{l}\text { Chicken } \\
\text { mortality }\end{array}$ & $46.35 \pm 0.74^{\mathrm{a}}$ & $39.92 \pm 0.32^{b}$ & $43.13 \pm 0.53$ & $* *$ & $37.12 \pm 0.23^{b}$ & $49.15 \pm 0.49^{\mathrm{a}}$ & $43.14 \pm 0.36$ & $* *$ & $* *$ \\
\hline
\end{tabular}

\subsection{Village Chicken producers profile and Egg Marketing Systems}

Table 4 presents profile of market participants. The study indicated that majority (59\%) of market participants who were selling chicken were females groups. Majority $(60 \%)$ of the respondents were attained elementary educational background. Market (83.3\%) was the first sources of information for all actors of market. Majority of the respondents preferred urban market $(89 \%)$ to sell their products.

\begin{tabular}{|c|c|c|c|c|c|c|}
\hline \multirow[b]{2}{*}{ Parameters } & \multirow[t]{2}{*}{ Description } & \multicolumn{4}{|c|}{ Market places $(\mathrm{N}=80)$} & \multirow{2}{*}{$\begin{array}{c}\text { Overall Mean } \\
\text { N }(\%)\end{array}$} \\
\hline & & $\begin{array}{c}G u b \\
\text { Frq }(\%)\end{array}$ & $\begin{array}{c}\text { End } \\
\text { Frq }(\%)\end{array}$ & $\begin{array}{c}\text { Yefek } \\
\text { Frq }(\%)\end{array}$ & $\begin{array}{c}\text { Aft } \\
\text { Frq }(\%)\end{array}$ & \\
\hline \multirow[t]{2}{*}{ Sex } & Male & $9(45)$ & $7(35)$ & $9(45)$ & $8(40)$ & $33(41)$ \\
\hline & Female & $11(55)$ & $13(65)$ & $11(55)$ & $12(60)$ & $47(59)$ \\
\hline \multirow[t]{4}{*}{ Marital status } & Married & $10(50)$ & $15(75)$ & $11(55)$ & $12(60)$ & $48(60)$ \\
\hline & Single & $7(35)$ & $2(10)$ & $4(20)$ & $3(15)$ & $16(20)$ \\
\hline & Divorced & $1(5)$ & $3(15)$ & $5(25)$ & $3(15)$ & $12(15)$ \\
\hline & Widowed & $2(10)$ & $0(0)$ & $0(0)$ & $2(10)$ & $4(5)$ \\
\hline \multirow{4}{*}{$\begin{array}{l}\text { Educational } \\
\text { background }\end{array}$} & Illiterate & $2(10)$ & $1(5)$ & $1(5)$ & $0(0)$ & $4(5)$ \\
\hline & Basic education & $5(25)$ & $2(10)$ & $6(30)$ & $7(35)$ & $20(25)$ \\
\hline & Elementary & $12(60)$ & $15(75)$ & $10(50)$ & $11(55)$ & $48(60)$ \\
\hline & High school & $1(5)$ & $2(10)$ & $3(15)$ & $2(10)$ & $8(10)$ \\
\hline \multirow{2}{*}{$\begin{array}{l}\text { Source of } \\
\text { information }\end{array}$} & Neighbors & $1(5)$ & $2(10)$ & $6(30)$ & $4(20)$ & $13(16.2)$ \\
\hline & Market & $19(95)$ & $18(90)$ & $14(70)$ & $16(80)$ & $67(83.8)$ \\
\hline \multirow[t]{2}{*}{ Market type } & Local(rural) & $0(0)$ & $2(10)$ & $3(15)$ & $4(20)$ & $9(11.2)$ \\
\hline & Urban & $20(100)$ & $18(90)$ & $17(85)$ & $16(80)$ & $71(88.8)$ \\
\hline \multirow{2}{*}{$\begin{array}{l}\text { Reasons for } \\
\text { Selling }\end{array}$} & HH income & $14(70)$ & $4(70)$ & $15(75)$ & $17(85)$ & $60(75)$ \\
\hline & Crop season & $6(30)$ & $6(30)$ & $5(25)$ & $3(15)$ & $20(25)$ \\
\hline
\end{tabular}

\subsection{Characteristics of village chicken marketing}

Village chicken and egg marketing characteristics are presented in Table 5. Both farm gate and primary markets were the major $(65 \%)$ market destination for village chicken producers where consumers and small traders/collectors directly purchase. On the other hand, only few $(20 \%)$ market respondents were transported chicken and eggs to secondary markets located at Endibir town, Arekit town, Wolkite and Woliso town, and sometimes transport to Butajira and Hossana during holydays. Besides, few sellers transported to tertiary/terminal markets of Addis Ababa. Only 15\% of the respondents reported there was death of birds during transportation to 
secondary and tertiary market.

Table 5. Marketing characteristics of chicken and egg $(\mathrm{N}=180 ; \mathrm{n}=90)$

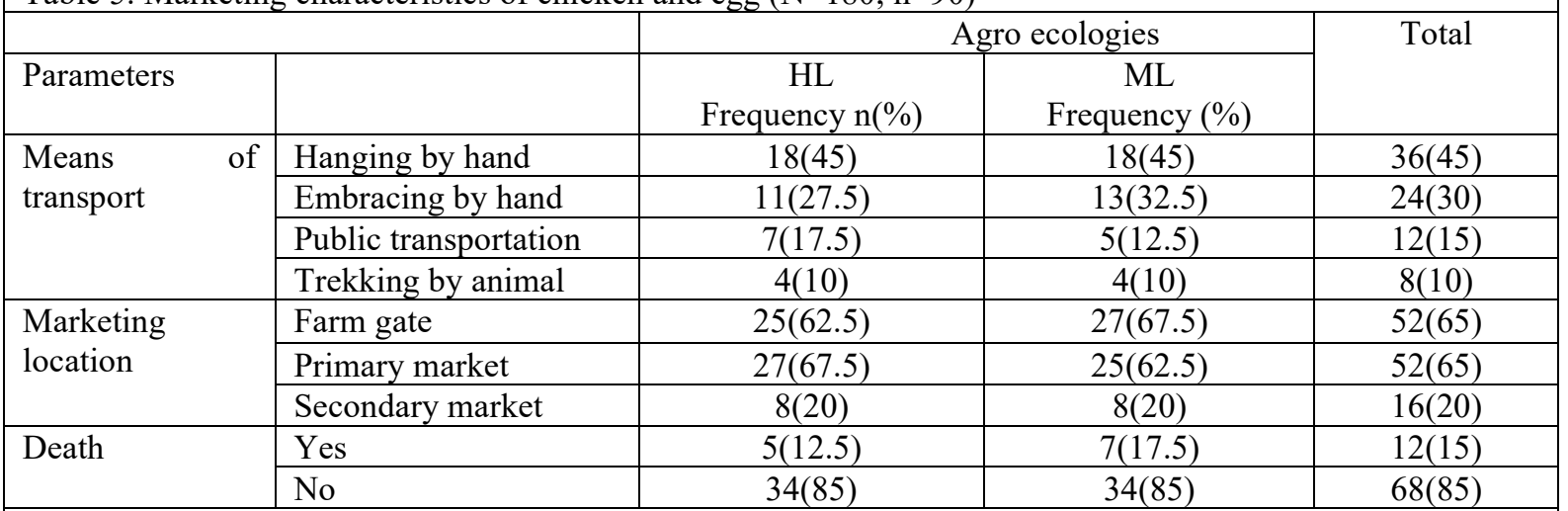

$H A, M A, N$ and $n$ represents High land, Mid land and total number of market participants, number of participants from the two altitudes, respectively.

\subsection{Chicken and egg price at different seasons, market type and occasions}

Price of chicken and egg at different market points, seasons and festive periods is presented in Table 6. Higher product price was recorded in secondary market both in chicken and egg. The price of products was almost double when compared between farm gate and secondary market. Even if the price of chicken is higher at all festive periods, the price of chicken became double at Ethiopian New year compared to any another festive periods of the year. Both Christian holidays and Ethiopian New Year times the price of chicken and eggs showed significance difference $(\mathrm{P}<0.05)$ among the PAs.

Table 6. Prices of chicken and eggs, and in seasons difference of the available market places (Mean of ETB \pm SE) Market places $(\mathrm{N}=80)$

Variables Gub End $\quad$ Yefek Aft SL

Local chicken (Adult)(Price per bird)

\begin{tabular}{|l|c|c|c|c|l|}
\hline Farm gate & $65.90 \pm 2.26$ & $75.10 \pm 1.89$ & $65.65 \pm 2.24$ & $64.85 \pm 1.88$ & - \\
\hline Primary market & $77.05 \pm 1.36$ & $88.90 \pm 1.30$ & $76.60 \pm 1.14$ & $75.25 \pm 1.60$ & - \\
\hline Secondary market & $143.85 \pm 3.71^{\mathrm{b}}$ & $167.10 \pm 2.36^{\mathrm{a}}$ & $141.55 \pm 3.41^{\mathrm{cd}}$ & $142.10 \pm 3.86^{\mathrm{cd}}$ & $*$ \\
\hline
\end{tabular}

Hybrid/crossbred chicken (Adult)

\begin{tabular}{|c|c|c|c|c|c|}
\hline Farm gate & $122.35 \pm 3.18$ & $127.25 \pm 2.75$ & $126.75 \pm 2.17$ & $123.65 \pm 3.17$ & - \\
\hline Primary market & $175.00 \pm 4.61$ & $189.25 \pm 6.35$ & $183.75 \pm 6.32$ & $181.00 \pm 6.35$ & - \\
\hline Secondary market & $250.00 \pm 8.67^{\mathrm{bc}}$ & $277.25 \pm 9.59^{\mathrm{a}}$ & $248.5 \pm 8.88^{\mathrm{bc}}$ & $251.3 \pm 10.08^{b}$ & $*$ \\
\hline \multicolumn{6}{|l|}{ Eggs } \\
\hline Farm gate & $2.71 \pm 0.04$ & $2.78 \pm 0.04$ & $2.77 \pm 0.05$ & $2.72 \pm 0.05$ & - \\
\hline Primary market & $3.07 \pm 0.05$ & $3.11 \pm 0.04$ & $3.11 \pm 0.05$ & $3.05 \pm 0.03$ & - \\
\hline Secondary market & $3.62 \pm 0.05^{\mathrm{c}}$ & $3.92 \pm 0.05^{\mathrm{a}}$ & $3.73 \pm 0.05^{b}$ & $3.51 \pm 0.06$ & $*$ \\
\hline \multicolumn{6}{|l|}{ Local chicken (Adult) } \\
\hline Christian holiday & $88.50 \pm 1.72^{\mathrm{bc}}$ & $99.40 \pm 1.30^{\mathrm{a}}$ & $87.95 \pm 1.86^{\mathrm{bc}}$ & $84.15 \pm 1.95$ & $*$ \\
\hline Muslim holiday & $65.55 \pm 2.97$ & $65.55 \pm 2.75$ & $67.15 \pm 2.85$ & $66.25 \pm 2.82$ & - \\
\hline Ethiopian New Year & $158.45 \pm 6.01^{\mathrm{bc}}$ & $181.40 \pm 3.64^{\mathrm{a}}$ & $160.10 \pm 5.07^{\mathrm{bc}}$ & $148.45 \pm 5.16$ & $*$ \\
\hline At any other time & $72.60 \pm 1.91$ & $77.75 \pm 1.61$ & $74.40 \pm 1.65$ & $72.85 \pm 2.03$ & - \\
\hline \multicolumn{6}{|c|}{ Hybrid/ crossbred chicken (Adult) } \\
\hline Christian holiday & $253.80 \pm 8.98^{\mathrm{b}}$ & $270.40 \pm 13.21^{\mathrm{a}}$ & $253.00 \pm 11.90^{\mathrm{c}}$ & $251.2 \pm 10.71$ & $*$ \\
\hline Muslim holiday & $223.20 \pm 14.36$ & $244.60 \pm 13.92$ & $232.85 \pm 13.46$ & $214.75 \pm 10.08$ & - \\
\hline Ethiopian New Year & $273 \pm 10.54$ & $291.00 \pm 11.94^{\mathrm{a}}$ & $280.00 \pm 8.20^{\mathrm{b}}$ & $278.00 \pm 10.59^{\mathrm{c}}$ & $*$ \\
\hline At any other time & $206.75 \pm 8.84$ & $205.25 \pm 9.83$ & $198.00 \pm 8.80$ & $204.00 \pm 9.62$ & - \\
\hline \multicolumn{6}{|l|}{ Eggs } \\
\hline Christian holiday & $3.72 \pm 0.09^{\mathrm{b}}$ & $3.97 \pm 0.08^{\mathrm{a}}$ & $3.55 \pm 0.09^{\mathrm{c}}$ & $3.40 \pm 0.09$ & $*$ \\
\hline Muslim holiday & $3.12 \pm 0.07$ & $3.35 \pm 0.09$ & $3.08 \pm 0.06$ & $3.15 \pm 0.09$ & - \\
\hline Ethiopian New Year & $3.82 \pm 0.05^{\text {bc }}$ & $3.99 \pm 0.24^{\mathrm{a}}$ & $3.82 \pm 0.04^{\mathrm{bc}}$ & $3.80 \pm 0.05$ & $*$ \\
\hline At any other time & $2.75 \pm 0.06$ & $2.75 \pm 0.6$ & $2.67 \pm 0.5$ & $2.72 \pm 0.05$ & - \\
\hline \multicolumn{6}{|c|}{$\begin{array}{l}N=\text { Number of total HHs;n=number of HHs from each distrit; SEM=Standard Error of Mean; ETB=Ethiopian } \\
\text { Birr; Gub= Gubrye; End=Endibr; Yefek=Yefekterek; Aft=Aftir; *=Significant at }(P=0.05) ; S L=\text { Significance } \\
\text { Levels }\end{array}$} \\
\hline
\end{tabular}




\subsection{Factors determining prices of chicken and eggs}

Price determining factors and chicken and eggs marketing constraints are presented in Table 7. A number of factors that could affect the prices of chicken were reported by respondents were seasonal demand, body size, sex, age, health status, plumage color, market site and status of chicken population in the market. Similarly, seasonal demand (holidays and fasting seasons) and religious festivals were also the major factors that determined the price of eggs. Other factors mentioned by the HHs in the district were sources of eggs (from local or exotic breed) and supply and demand.

\begin{tabular}{|c|c|c|c|c|c|c|}
\hline \multirow{3}{*}{$\begin{array}{l}\text { Factors } \\
\text { Seasonal demand }\end{array}$} & \multicolumn{4}{|c|}{ Market places } & \multirow{2}{*}{\multicolumn{2}{|c|}{$\begin{array}{c}\text { Total Mean } \\
\text { N }(\%)\end{array}$}} \\
\hline & \multirow{2}{*}{$\begin{array}{l}\text { Gub } \\
\text { Frq(\%) } \\
3(15)\end{array}$} & \multirow{2}{*}{$\begin{array}{l}\text { End } \\
\text { Frq(\%) } \\
4(20) \\
\end{array}$} & \multirow{2}{*}{$\begin{array}{l}\text { Yefek } \\
\text { Frq(\%) } \\
7(35)\end{array}$} & \multirow{2}{*}{$\begin{array}{l}\text { Aft } \\
\text { Frq(\%) } \\
6(30)\end{array}$} & & \\
\hline & & & & & $20(25)$ & 2 \\
\hline Body weight & $5(25)$ & $4(20)$ & $2(10)$ & $2(10)$ & $13(16.2)$ & 4 \\
\hline Sex of the chicken & $4(20)$ & $3(15)$ & $0(0)$ & $3(15)$ & $10(12.5)$ & 6 \\
\hline Age of the chicken & $1(5)$ & $2(15)$ & $6(30)$ & $1(5)$ & $10(12.5)$ & 6 \\
\hline Health status of the bird & $5(25)$ & $0(0)$ & $1(5)$ & $3(15)$ & $9(11.2)$ & 7 \\
\hline Seasonal demand & $9(45)$ & $10(50)$ & $7(35)$ & $12(60)$ & $38(47.5)$ & 1 \\
\hline Religious festivals & $3(15)$ & $5(25)$ & $5(25)$ & $5(25)$ & $18(22.5)$ & 3 \\
\hline Egg source & $4(20)$ & $1(5)$ & $5(25)$ & $3(15)$ & $13(16.2)$ & 4 \\
\hline Supply and demand & $4(20)$ & $4(20)$ & $3(15)$ & $0(0)$ & $11(13.8)$ & 5 \\
\hline Price fluctuation $^{*}$ & $6(30)$ & $6(30)$ & $7(35)$ & $7(35)$ & $26(32.5)$ & 1 \\
\hline Demand seasonality $^{*}$ & $5(25)$ & $2(10)$ & $5(25)$ & $4(20)$ & $16(20)$ & 2 \\
\hline Intermediaries $^{*}$ & $5(25)$ & $3(15)$ & $2(10)$ & $4(20)$ & $14(17.5)$ & 3 \\
\hline Disease outbreak $^{*}$ & $0(0)$ & $2(10)$ & $4(20)$ & $3(15)$ & $9(11.3)$ & 4 \\
\hline Lack of information ${ }^{*}$ & $3(15)$ & $4(20)$ & $1(5)$ & $1(5)$ & $9(11.2)$ & 5 \\
\hline Limited market access" & $1(5)$ & $3(15)$ & $1(5)$ & $1(5)$ & $6(7.5)$ & 6 \\
\hline
\end{tabular}

\section{Discussion}

The result revealed that mid land agro ecology has higher average chicken holding numbers as compare to high land agro ecology HHs of the study area. The lower average chicken holding of high land agro ecology might be attributed to mortality of chicken due to low temperature stress. In addition, health service accessibility and availability of replacement stock in the mid land might higher the average chicken holding of chicken per HHs in midland agro ecology. The study area average chicken population is slightly lower than the country average chicken population/HH i.e., 12 chicken/HHs. In addition, finding of Samson \& Endalew (2010) and Fisseha et al. (2010b) who reported 12 chickens/ HH in Mid Rift Valley of Oromia, and 13.10 and 12.38 chickens/HH in Bure and Fogera districts, respectively were also showed a higher chicken population in comparable study areas. In the contrary, the result of this study has slight higher average number increase of chicken population as compared to Aman et al. (2015) and Meseret (2010) who reported average chicken population of 8.6and 6.23 per $\mathrm{HH}$ in Kambata Tambaro and Wolaita zones, respectively. Availability of farms which can produce replacement stock and distribute to village chicken producers nearer to the study area can be the benefit for having higher average chicken population as compared to the above findings.

Gurage community has been supporting their livelihood majorly from cropping, large and small ruminant production and remittance from family members who dwell on urban parts of the country. Besides, village chicken production is a quick income means especially for female members of the family. This result in agreement with Mekonnen (2007); Fisseha et al (2010) and Matiwos et al. (2013) who indicated a remarkable portion of the total HHs kept chicken as a source of family income. The exhibited differences might be attributed to different in climatic condition, breed difference and feeding difference (Matiwos et al., 2013; Alem, 2014). The higher average egg production per hen per clutch within the agro ecologies and breeds of village chicken is in line with Samson and Endalew (2010) in Mid Rift Valley of Oromia, Ethiopia. The number of eggs produced from local chicken breeds was too much lower than the exotic and crossbred chicken. The result of the current study in relation to the number of produced egg is in line with the report of Bikila et al. (2015). On the other hand, the average number of egg produced in the study area was higher than Meseret (2010) and lowers than Melkamu (2014) in Gomma and Enebsie Sar Midir districts of Ethiopia, respectively. The low egg production capacity of local breeds as compared to the crossbred might be attributed to the genetic potential of the breed and village chicken production system rely on scavenging feed rather than provision of necessary nutrient through formulate feed. Aklilu et al. (2017) also indicated that the main reasons for local chicken low productivity are poor feed availability, disease and low 
genetic potential.

Even if the husbandry practice invested for the two breeds are the same, the major reason for local chicken eggs higher hatchability as compared to crossbred chicken might be attributed to, local breeds are more accustomed to scavenging and feeding themselves independently and nesting to lay egg than exotic and crossbred chicken. In addition, the researchers have been personally observing that chickens with a higher level of exotic blood have not been comfortable with the village chicken production system due to the system obliges to compete for food, water, nesting, perching and brooding area...etc for survive and productivity. Hence, feed shortage and improper brooding areas can lead egg quality to be deteriorated both internally and externally. The current result was in agreement with the result of Fisseha et al. (2010) who reported that hatchability level of egg from local chickens in Bure and Fogera districts of Ethiopia were $82.6 \%$ and $78.9 \%$, respectively. The result of the current study was significantly higher than the report of Ahmedin \& Mangistu(2016) who indicated a hatchability level of $67.78 \%$ in Gorogutu district, Eastern Hararge zone of Ethiopia. In the contrary, higher (85.8\%) village chicken hatchability performance was indicated in central Tigray, Ethiopia (Alem, 2014).

Significantly $(\mathrm{P}<0.01)$ higher chicken mortality rate was reported for crossbred chickens, and also there was an interaction effect between the two breeds and agro ecologies in chicken mortality and hatchability. This result is in agreement with the finding of Fisseha et al.(2010), Aklilu et al. (2017) and Mekonnen (2007) who reported higher chicken mortality rate of $24-56 \%, 51 \%$ and $55.8 \%$, respectively. Chicken producers were obliged forced to sell their chicken and egg directly to consumers and/or small retailers majorly at farm gate and primary market. Personal observation of the researcher and opinions of FGD participants indicated that the predominant means of chicken transportation to market was by hand, and similar habits was exhibited in most village chicken producers of the country. Prices were also higher during public and religious holidays. Particularly during the Ethiopian New Year and Christian holidays (Meskel, Christmas and Easter) the average price of chicken and egg was higher than any festive periods. However, no critical chicken and egg price difference was observed during Muslim holidays. This might be due to no special demand of chicken products were demands for celebrating the holidays after the end of fasting period. In general, producers in the study area did not receive a fair price for their product as they had no access to permanent market places and lack of formal and organized market value chain in the village/nearby. The current result is in line with the finding of Fisseha (2009) and Meseret (2010) who reported unstable price and seasonal demand of chicken and egg marketing. The FGDs also indicated that lower prices of chicken and chicken products were recorded in rainy seasons as compared dry season. This might be due to high prevalence of diseases and predators, the high supply of chicken products during the beginning of the rainy season when incidence of disease is high, lack of feed and climate change. The fluctuation in price of chicken and egg and varied seasonal demand coupled up with unnecessary interference of middle man have been challenging the chicken and egg marketing not to be predictable. The result of the current study was in line with; Matiwos et al.(2013); Hunduma et al. (2010) who reported seasonal price fluctuation and lack of access to market were the first two primary constraint. Aklilu et al. (2007) indicated that involvement of intermediaries as the primary constraint which influences egg and chicken marketing. In the contrary, Meseret (2010) indicated that disease outbreak, holidays and festive periods were the primary influencing factor of chicken and egg price fluctuation. Moreover, lack of organized marketing system and absence of packaging and weight standardization for eggs was reported as chicken and egg production constraint by Matiwos et al. (2013) and Bosenu \& Takele (2014) and FAO (2008b), respectively. The result of the current study is in agreement with Fisseha et al. (2010) and Aklilu et al. (2007) who indicated that involvement of intermediaries in the marketing channel leads to decreases the prices of chicken and eggs. As well, Dawit (2010) reported a shorter market channel for both chicken and eggs in Alamata and Atsbi-Wonberta districts of Tigray region.

\section{CONCLUSION}

The overall results revealed that village chicken producers rely on their young chicken and hens. House wives are still the basic actors in village chicken production in addition to other $\mathrm{HH}$ activities. Marketing activity of poultry product is still strongly depends on holydays and festive periods. Producers are not that much benefited from chicken producers as compared to other market actors. Strong intervention should be invested on female members of the $\mathrm{HH}$ rather than male members. All variables used to estimate village chicken productivity showed a significant difference among the selected study areas within the same agro ecology and between the selected agro ecologies. Price difference was exhibited on all chicken and egg produced and sold in secondary market of the study areas.

\section{Availability of data and materials}

The data that support the findings of this study can be obtained from the authors based on request.

\section{Acknowledgements}

The authors are grateful to the communities of Gurage zone for their cooperation in providing information and in 
the course of data collection.

\section{Conflicts of Interest}

The authors declare that there are no conflicts of interest

\section{REFERENCES}

Abdullah AS, Hitchman SC, Driezen P, Nargis N, Quah AC and Fong GT. (2011). Socioeconomic differences in exposure to tobacco smoke pollution (TSP) in Bangladeshi households with children.Findings from International Tobacco Control (ITC) Bangladesh Survey. International Journal of Environment, Resourceand Public Health Mar. Vol. 8, No. 3, pp. 842-860. doi: 10.3390/ijerph8030842. Epub 2011 Mar 15.

Ahmedin A and Mangistu U. (2016). Evaluation of fertility, hatchability and egg quality of rural chicken in Gorogutu district, Eastern Hararghe, Ethiopia. Asian Journal of Poultry Science.Vol. 10, pp. 111-116.

Aklilu H, Berhanu G and Tegegne A. (2017). Status and drivers of village poultry production and its efficiency in Ethiopia. NJAS-Wageningen Journal of Life Sciences. Vol. 83, pp. 3038. https://scialert.net/abstract/?doi=ajpsaj.2016.111.116.

Aklilu H. (2007). Village poultry in Ethiopia; Socio-technical analysis and learning with households. PhD Thesis, Wageningen University, Wageningen, the Netherlands.

Alem T. Yaynashet T and Aklilu H. (2014). Socio-economic characteristics of poultry production in lowland and midland agro-ecological zones of central Tigray region, Ethiopia. DOI:10.5897/IJLP2013.0153.

Alemayehu G. (2017). Characterization of scavenging and intensive chicken production and marketing system in Lume district, East Shewa zone, Oromia region, Ethiopia. Msc Thesis, Haramaya University, Ethiopia.

Aman G, Fitsum T, Mesfin M, Addisu J and Bereket Z. (2015). Assessment of village chicken production systems in KambataTambaro and Wolaita zones, SNNPR, Ethiopia. Global Journal of Science. pp. 2249-4626. ISSN: 2249-4626 \& Print ISSN: 0975-5896.

Bikila N, Mengistu U, Negassi A and Fereja GB. (2015). Study of production practices, and productivity of village chicken in Chelliya district, Ethiopia. Journal of Science, Technology and Arts Research. Vol. 4, No. 3, pp. 117-122.

Bosenu A and Takele G. (2014). Study on challenges and opportunities of village chicken production in Haramaya District, Eastern Ethiopia. International Journal of Scientific and Research Publications. Vol. 4, No. 12, pp. 2250-3153. www.ijsrp.org.

CSA. (2016). Report on livestock and livestock characteristics. Agricultural sample survey, volume II, statistical bulletins 583, Federal Democratic Republic of Ethiopia.

Dawit G. (2010). Market chain analysis of poultry: the case of Alamata and AtsbiWonberta districts of Tigray region. MSc Thesis, Haramaya University, Ethiopia.

De Bruyn J, Wong J, Bagnol B, Pengelly B and Alders R. (2015). Family poultry production and food and nutrition security. Vol. 10, No. 1, pp. 1-9. DOI: 10.1079/PAVSNNR201510013.

Emebet M, Singh H, Tesefaye S, Anna MJ. (2014). Phenotypic characterization of indigenous chicken populations in South-West and South part of Ethiopia. British Journal of poultry Sciences. Vol. 1, No. 1, pp. 15-19. DOI: 10.5829/idosi.bjps.2014.3.1.8370.

FAO. (2008b). HPAI prevention and control strategies in East Africa. The Structure, marketing and importance of commercial and village poultry industry: An Analysis of Poultry Sector in Ethiopia. Food and Agricultural Organization.

FAO. (2010). Smallholder poultry production- livelihoods, food security and socio cultural significance, by Kryger KN, Thomson KA, Whyte MA and Dissing M.Food and Agricultural Organization. Smallholder Poultry Production.

Fisseha M, Abera M and Tadelle D. (2010a). Assessment of village chicken production system and evaluation of the productive and reproductive performance of local chicken ecotype in Bure district, North-West Ethiopia. African Journal of Agricultural Research. Vol. 5, No. 13, pp. 1739-1748.

Fisseha M, Azage T and Tadelle D. (2010b). Local chicken production and marketing systems in Ethiopia: Characteristics and opportunities for market-oriented developments. IPMS (Improving Productivity and Market Success) of Ethiopian households. Nairobi, Kenya. ILRI.No.24.www.ipmsethiopia.org.www.eap.gov.et.

Fisseha M. (2009). Studies on production and marketing system of local chicken ecotypes in Bure Woreda, NorthWest Amhara. MSc Thesis, Hawassa University, Ethiopia.

Fissiha M, Mellesse T, and Dessie A. (2010). Assessment of village chicken production system and evaluation of the productive and reproductive performance of local chicken ecotype in Bure district, North West Ethiopia. African Journal of Agricultural Research.Vol. 5.No. 13. Pp. 1739-1748. www.academicjournals.org/AJAR.

Hunduma D, Regassa C, Fufa D, Endale B and Samson L. (2010). Major constraints and health management of village poultry production in rift valley of Oromia, Ethiopia. Global Veterinarian. Vol. 5, No. 1, pp. 1992- 
6197.

Lawal TE, Owoseni A, Atobatele OE, Ademola SG and Akomolafe DO. (2016). Evaluation of the nutritive value of citrus pulp degraded with Penicilliumnotatum and Penicilliumcitrinum. American Journal of Research Communication. Vol.4, No. 9, pp. 130-140. www.usa-journals.com.

Mammo M. (2012). Indiginous chicken production and the innate characteristics (Review). Asian Journal of Poultry Science. Vol. 6, No. 2, pp. 56-64. https://scialert.net/abstract/?doi=ajpsaj.2012.56.64.

Matiwos H, Negassi A, Solomon D. (2013). Production performance of local and exotic breeds of chicken at rural household level in Nole Kabba Woreda, Western Wollega, Ethiopia. African Journal of Agriculture Research. Vol. 8. No. 11, pp. 1014-1021.

Mekonnen G. (2007). Characterization of smallholder poultry production and marketing system of Dale, Wonsho and Loka Abaya districts of Southern Ethiopia. MSc Thesis, Hawassa University, Ethiopia.

Melkamu B. (2014). Performance evaluation of local chicken at Enebsie Sar Midir Woreda, Eastern Gojjam, Ethiopia, Global Journal of Agriculture and Food Sciences Research. Vol. 1, No. 2, pp. 1-8. www.gbjournals.org.

Meseret M. (2010). Characterization of village chicken production and marketing system in Gomma Woreda, Jimma zone, Ethiopia. MSc Thesis, Jimma University, Ethiopia.

Negussi D, Tadele D, Vander Waaij LH and Van Arendonk JAM. (2010). Morphological features of indigenous chicken populations of Ethiopia. Animal Genetic Resources. No. 46, pp. 11-23. doi:10.1017/S2078633610000652

Nigussie D. (2010). Breeding programs for local chicken in Ethiopia: analysis of diversity in production systems and chicken populations. PhD Dissertation, Wageningen University, the Netherlands.

Samson L and Endalew B. (2010). Survey on Village Based Chicken Production and Utilization System in Mid Rift Valley of Oromia, Ethiopia. Global Veterinarian. Vol. 5, No. 4, pp. 198-203.

Shapiro BI, Gebru G, Desta S, Negassa A, Nigussie K, Aboset G and Mechal H. (2015). Ethiopia livestock master plan. ILRI.Project Report. Nairobi, Kenya.

Tadesse A, and Tesfay Y. (2013). Flock dynamics and composition of rural chickens in lowland and midland agroecological zones of central Tigray North Ethiopia. Livestock Research for Rural Development. Vol. 7, No. 25. http://www.lrrd.org/lrrd25/7/alem25126.htm.

USAID. (2010). Partnership for safe poultry in Kenya (PSPK) Program. United States Agency for International Development. Regional Poultry Value Chain Analysis. 